\title{
The Caddo Ceramic Sherd Assemblage from the Hawkins Site (41SM144) on the Sabine River in Smith County, Texas
}

Timothy K. Perttula

Heritage Research Center, Stephen F. Austin State University

Follow this and additional works at: https://scholarworks.sfasu.edu/ita

Part of the American Material Culture Commons, Archaeological Anthropology Commons, Environmental Studies Commons, Other American Studies Commons, Other Arts and Humanities Commons, Other History of Art, Architecture, and Archaeology Commons, and the United States History Commons

Tell us how this article helped you.

This Article is brought to you for free and open access by the Center for Regional Heritage Research at SFA ScholarWorks. It has been accepted for inclusion in Index of Texas Archaeology: Open Access Gray Literature from the Lone Star State by an authorized editor of SFA ScholarWorks. For more information, please contact cdsscholarworks@sfasu.edu. 
The Caddo Ceramic Sherd Assemblage from the Hawkins Site (41SM144) on the Sabine River in Smith County, Texas

\section{Creative Commons License}

\section{(c) (1) \&}

This work is licensed under a Creative Commons Attribution-NonCommercial 4.0 International License 


\title{
The Caddo Ceramic Sherd Assemblage from the Hawkins Site (41SM144) on the Sabine River in Smith County, Texas
}

\author{
Timothy K. Perttula
}

\section{Introduction and Setting}

The Hawkins site is an ancestral Caddo habitation site on a Sabine River bluff about $1.7 \mathrm{~km}$ southwest of the confluence of Little White Oak Creek with the river, in the Pineywoods of Smith County (Figure 1). The site was located and investigated in the 1950s by Sam Whiteside of Tyler, Texas. This article is concerned with the analysis of the Caddo ceramic wares from the site, as well as an assessment of the probable age and cultural affiliation of the Caddo occupation.

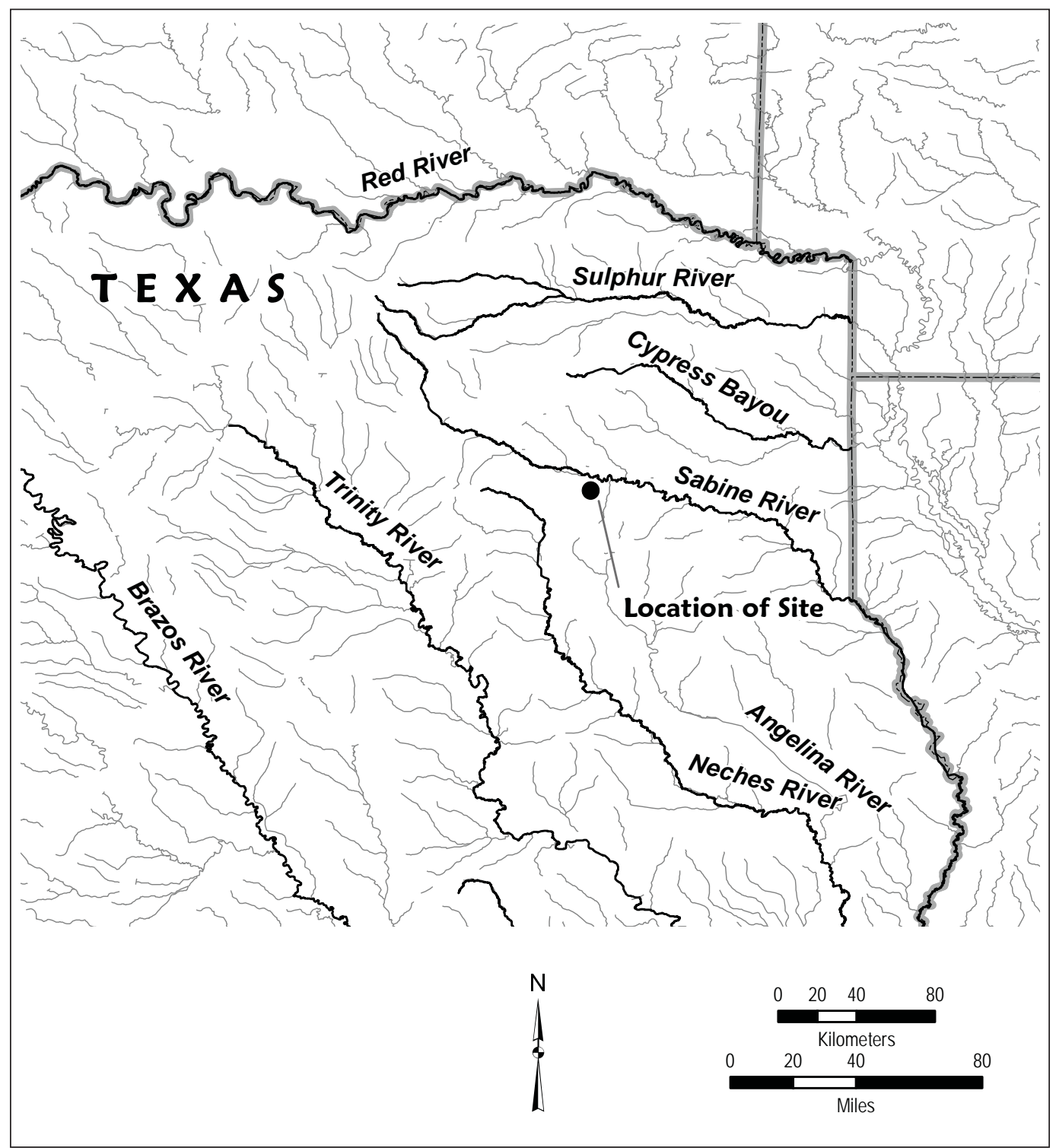

Figure 1. Location of the Hawkins site (41SM144) in East Texas. 


\section{Ceramic Sherd Assemblage}

There is a total of 71 sherds in the assemblage from the Hawkins site. The sherds are from plain ware, fine ware, and utility ware vessels (Table 1). About 44 percent of the rim sherds are from plain ware carinated bowls, bowls, and bottles, and another 41 percent of the rims are from fine ware vessels.

Table 1. Ceramic sherds from the Hawkins site (41SM144).

\begin{tabular}{lllllll}
\hline Ware & Rim & Body & Base & Grog-temper & Bone-temper & N \\
\hline Plain & 12 & 26 & 4 & 34 & 8 & 42 \\
Fine & 11 & 11 & - & 21 & - & 22 \\
Utility & 4 & 3 & - & 7 & 62 & 7 \\
\hline Totals & 27 & 40 & 4 & 62 & 9 \\
\hline
\end{tabular}

More than 87 percent of the sherds from the site are from grog-tempered vessels (see Table 1). Bonetempered sherds are best represented in the plain wares (19 percent), and only 4.5 percent of the fine ware sherds are from bone-tempered vessels; none of the utility ware sherds are from bone-tempered vessels. One of the plain ware rims has a flattened and wide Redwine mode lip (see Walters 2010), a form of lip treatment noted in Middle Caddo period contexts in this part of the Sabine River basin.

The decorated sherds from the Hawkins site are dominated by fine ware sherds ( 76 percent of the decorated sherd sample and 73 percent of the decorated rim sherds, see Table 1). Utility ware sherds comprise only 24 percent of the decorated sherds in the assemblage.

The fine ware sherds include sherds from engraved ( $\mathrm{n}=19)$, engraved-excised $(\mathrm{n}=1)$, excised $(\mathrm{n}=1)$, and red-slipped ( $\mathrm{n}=1$ ) vessels (Table 2); the red-slipped sherd is from a Sanders Slipped vessel (Perttula et al. 2016).

Table 2. Decorated methods and elements in the fine ware and utility ware sherds from the Hawkins site.

\begin{tabular}{|c|c|c|c|}
\hline Decorative method/decorative element & Rim & Body & $\mathrm{N}$ \\
\hline \multicolumn{4}{|l|}{ Fine Ware } \\
\hline \multicolumn{4}{|l|}{ Engraved } \\
\hline cross-hatched engraved lines & 1 & - & 1 \\
\hline curvilinear engraved lines & 1 & 3 & 4 \\
\hline diagonal engraved lines & 1 & - & 1 \\
\hline diagonal engraved lines and diagonal hatched ladders & - & 1 & 1 \\
\hline diagonal opposed engraved lines & 1 & - & 1 \\
\hline horizontal engraved lines & 2 & 1 & 3 \\
\hline horizontal and curvilinear engraved lines & 1 & - & 1 \\
\hline horizontal and diagonal engraved lines & 1 & 2 & 3 \\
\hline $\begin{array}{l}\text { horizontal and opposed curvilinear engraved lines and } \\
\text { hatched triangular zone }\end{array}$ & 1 & - & 1 \\
\hline horizontal and vertical engraved lines & - & 1 & 1 \\
\hline straight engraved line & - & 2 & 2 \\
\hline \multicolumn{4}{|l|}{ Engraved and Excised } \\
\hline $\begin{array}{l}\text { curvilinear zones filled with diagonal and cross-hatched } \\
\text { lines and excised hole on the wide and flattened lip }\end{array}$ & 1 & - & 1 \\
\hline \multicolumn{4}{|l|}{ Excised } \\
\hline excised hole on the wide and flat lip & 1 & - & 1 \\
\hline
\end{tabular}


Table 2. Decorated methods and elements in the fine ware and utility ware sherds from the Hawkins site, cont.

\begin{tabular}{llll}
\hline Decorative method/decorative element & Rim & Body & $\mathrm{N}$ \\
\hline $\begin{array}{l}\text { Red-slipped } \\
\text { Exterior red-slipped }\end{array}$ & - & 1 & 1 \\
$\begin{array}{l}\text { Utility Ware } \\
\text { Appliqued } \\
\quad \text { curvilinear appliqued ridge and clusters of appliqued nodes }\end{array}$ & - & & 1 \\
$\begin{array}{l}\text { Incised } \\
\text { cross-hatched incised lines } \\
\text { cross-hatched and horizontal incised lines }\end{array}$ & 1 & \\
$\quad$ diagonal incised lines & - & 1 & 1 \\
diagonal opposed incised lines & 1 & - & 2 \\
$\begin{array}{l}\text { Incised-Appliqued } \\
\text { horizontal incised lines above series of appliqued nodes }\end{array}$ & 2 & - & 1 \\
\hline Totals & 1 & - & 1 \\
\hline
\end{tabular}

The engraved rim sherds have horizontal, diagonal, and cross-hatched decorative elements (see Table 2) as well as diagonal opposed engraved lines from a Sanders Engraved carinated bowl (Figure 2a). There are also rims with sets of curvilinear engraved lines (Figure 2e), and other rims with horizontal and diagonal (Figure 2f) engraved lines and horizontal and vertical curvilinear engraved lines (Figure 2g). One distinctive rim may be an early stylistic version (ca. 14 $4^{\text {th }}$ century A.D.) of Poynor Engraved, var. Cook (see Perttula 2011:Figure 6-64d) with horizontal and opposed curvilinear engraved lines and a hatched triangular zone (Figure $2 \mathrm{~h}$ ).

A lower rim of a carinated bowl has both diagonal engraved lines and narrow diagonal zones or ladders filled with diagonal hatched lines (see Figure $2 b$ ). Another carinated bowl sherd has both diagonal engraved lines and a set of diagonal and horizontal engraved lines on the rim panel (see Figure 2d).

The engraved bottle sherds in the fine wares from the Hawkins site feature sets of curvilinear engraved lines on vessel bodies (see Figure 2c) or a set of horizontal and diagonal or vertical engraved lines. One bottle sherd has at least two horizontal engraved lines on the body below the bottle neck.

The one engraved-excised rim sherd in the fine wares from the site is from a vessel with rim peaks and a wide flattened lip. On the rim itself are curvilinear engraved zones filled with either diagonal or crosshatched engraved lines (see Figure 2i). There is a large excised and drilled hole on the lip of the vessel (see Figure 2i'). Similar vessels with small excised holes on the rim peaks include East Incised bowls of early to Middle Caddo period age (ca. A.D. 900-1400) from the Crenshaw site on the Red River in southwestern Arkansas (Suhm and Jelks 1962:Plate 21j; Perttula et al. 2014:Figure 148, 150). The one excised rim sherd in the Hawkins site collection has a wide lip and a rim peak, with an excised circular hole on the flattened lip.

Five of the utility ware sherds have incised decorative elements (see Table 2). This includes a Canton Incised rim with diagonal opposed lines (Figure 3c), a Canton Incised rim with cross-hatched lines in a zone on the rim panel, above a horizontal incised line at the rim-body juncture (Figure 3d), and diagonal incised lines (with the incised lines running from right to left across the rim). One body sherd has cross-hatched incised lines. 


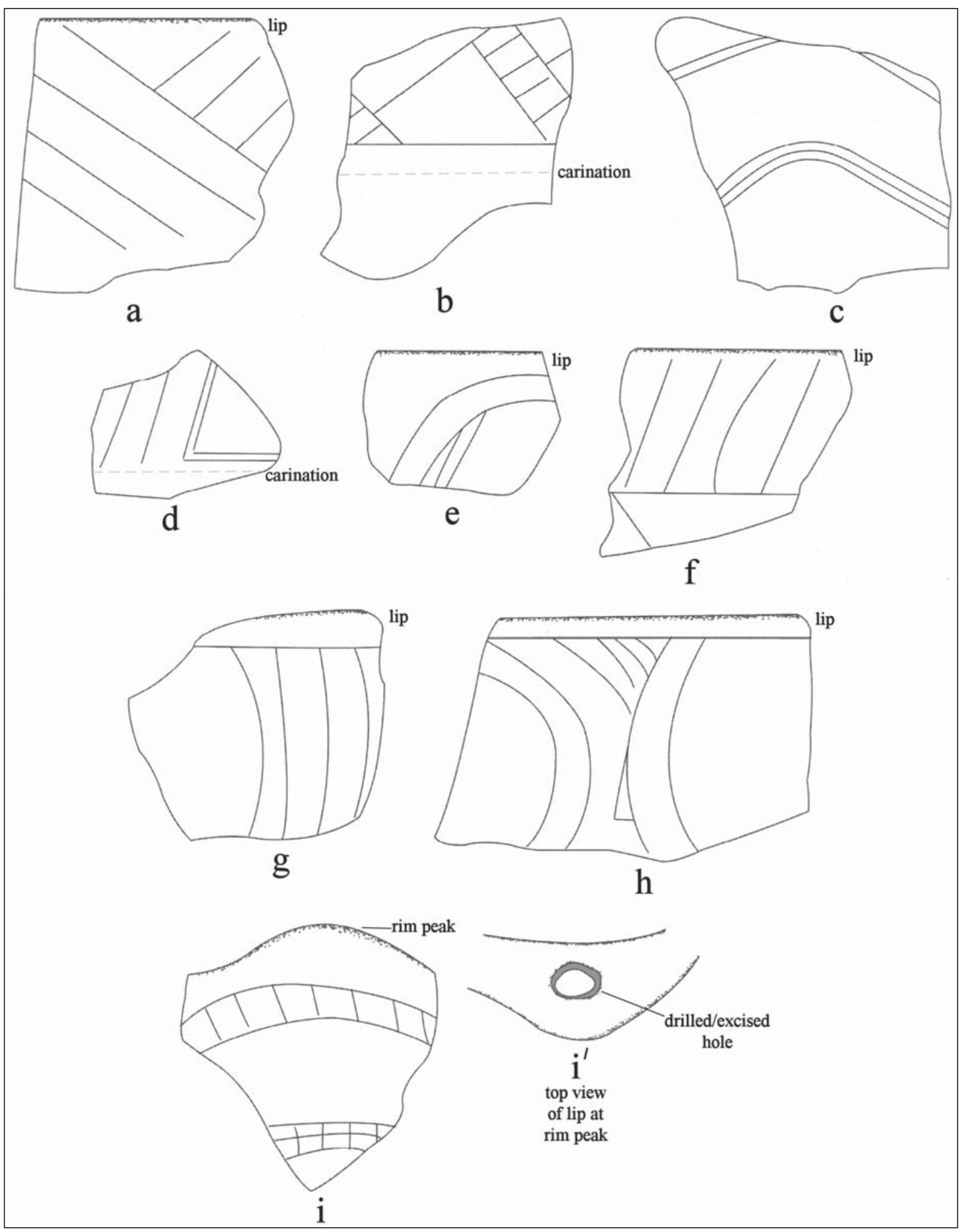

Figure 2. Selected decorative elements on fine ware sherds from the Hawkins site (41SM144). 


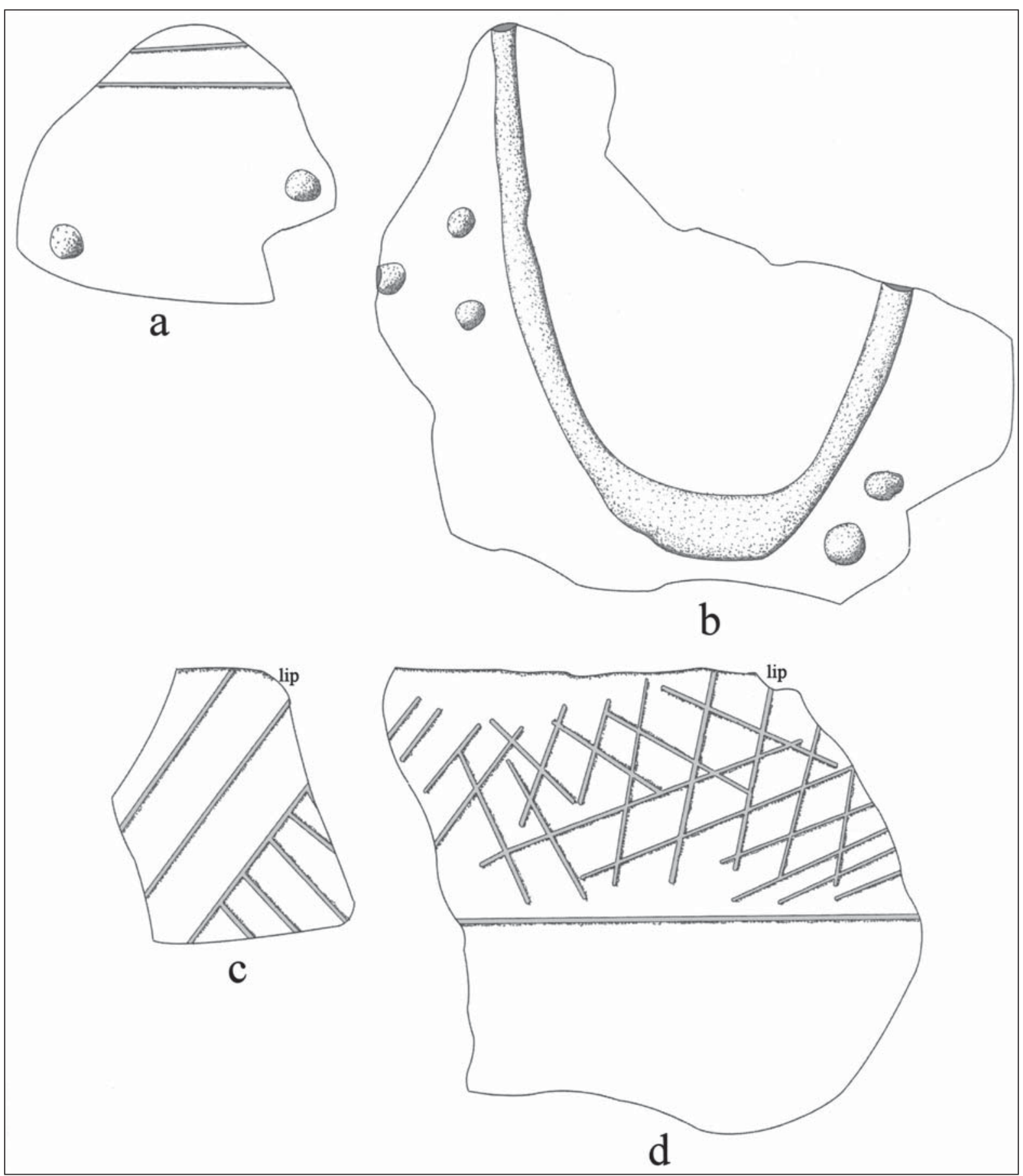

Figure 3. Selected decorative elements on utility ware sherds from the Hawkins site (41SM144): a, incisedappliqued body sherd; b, appliqued body sherd; c-d, incised rim sherds.

One of the other utility ware sherds from the Hawkins site has at least three horizontal incised lines on a jar rim panel, and widely spaced appliqued nodes on the vessel body (see Figure 3a). A large body sherd found at the site has a single large curvilinear appliqued ridge as well as at least two clusters of small appliqued nodes (see Figure 3b). 


\section{Summary and Conclusions}

The Hawkins site (41SM144) is an ancestral Caddo settlement on the Sabine River in the East Texas Pineywoods. Investigations at the site in the 1950s recovered a small but distinctive ceramic sherd assemblage primarily from jars, bowls, carinated bowls, and bottles tempered with grog.

The fine ware sherds are from carinated bowls and bottles, as well as one red-slipped Sanders Slipped bowl. The fine ware sherds have a variety of decorative elements that feature vessels with hatched ladder elements, diagonal opposed Sanders Engraved rim sherds, bottle sherds with sets of curvilinear engraved lines, and other vessels with horizontal and diagonal or sets of curvilinear engraved lines. Two rims with wide and flattened lips have large excised and drilled circular holes on the lip, similar to East Incised vessels from Red River contexts. One rim in the assemblage is from a probable Poynor Engraved, var. Cook carinated bowl with opposed curvilinear engraved lines and an associated hatched pendant triangle.

The utility wares are from Canton Incised jars, and there are incised-appliqued and appliqued jar sherds that feature small appliqued nodes on the vessel body. It is notable that there are no brushed utility ware sherds in the assemblage, as brushed utility ware jars are a common part of post-A.D. 1200 Caddo ceramic assemblages in many parts of East Texas (Perttula 2015). However, Caddo ceramic assemblages without considerable amounts of brushed sherds occur in the upper Sabine, Sulphur, and Red River basins, as is the case at the Early and Middle Caddo period Jamestown site (41SM54, 1.1 percent brushed, Perttula and Walker 2008), the Wolf site (41SM195, 0.0 percent brushed, Walters 2003), and 41SM53 (1.8 percent brushed, Walters and Perttula 2015).

The preponderance of the evidence regarding the kinds of decorated sherds in the assemblage from the Hawkins site (41SM144) suggests that the ancestral Caddo occupation there took place during the Middle Caddo period, perhaps between ca. A.D. 1300-1400. It may be a habitation site that was associated socially and politically with the Middle Caddo period Jamestown mound center not far to the west in the Sabine River basin.

\section{Acknowledgments}

My thanks to Mark Walters for providing the opportunity to study the Caddo sherds from the Hawkins site (41SM144). Lance Trask prepared the figures in this article.

\section{References Cited}

Perttula, T. K.

2011 The Ceramic Artifacts from the Lang Pasture Site (41AN38) and the Place of the Site within an Upper Neches River Basin Caddo Ceramic Tradition. In Archeological Investigations at the Lang Pasture Site (41AN38) in the Upper Neches River Basin of East Texas, assembled and edited by T. K. Perttula, D. B. Kelley, and R. A. Ricklis, pp. 145-320. Archeological Studies Program Report No. 129, Texas Department of Transportation, Environmental Affairs Division, Austin.

2015 East Texas Caddo Ceramic Sherd Database. Journal of Northeast Texas Archaeology 51:1-46.

Perttula, T. K. and C. P. Walker

2008 The History of Archaeological Investigations and Geophysical Survey at the Jamestown Mound Site (41SM54), an Archaeological Conservancy Preserve in Smith County, Texas. Report of Investigations No. 92. Archeological \& Environmental Consultants, LLC, Austin.

Perttula, T. K., M. Walters, and B. Nelson

2016 Caddo Ceramic Vessels from the T. M. Sanders Site (41LR2) on the Red River in Lamar County, Texas. Special Publication No. 41. Friends of Northeast Texas Archaeology, Austin and Pittsburg. 
Perttula, T. K., B. Nelson, M. Walters, and R. Cast

2014 Documentation of Caddo Funerary Objects from the Crenshaw Site (3MI6) in the Gilcrease Museum Collections. Special Publication No. 19. Friends of Northeast Texas Archaeology, Pittsburg and Austin.

Suhm, D. A. and E. B. Jelks (editors)

1962 Handbook of Texas Archeology: Type Descriptions. Special Publication No. 1, Texas Archeological Society, and Bulletin No. 4, Texas Memorial Museum, Austin. Reprinted in 2009, Gustav's Library, Davenport, Iowa.

Walters, M.

2003 The Wolf Site (41SM195), Smith County, Texas. Journal of Northeast Texas Archaeology 18:1-21.

Walters, M., with contributions by T. Middlebrook and T. K. Perttula

2010 Redwine or Pie-Crust Mode Forms in East Texas Caddo Ceramics and comparisons with Sprocket-Rims of Southwest Arkansas. Caddo Archeology Journal 20:77-128.

Walters, M. and T. K. Perttula

2015 Sam Whiteside's Prairie Creek Sites in Smith County, Texas. Journal of Northeast Texas Archaeology $58: 1-12$. 